\title{
PEMETAAN POTENSI EKOWISATA WILAYAH PESISIR DI KABUPATEN BULELENG
}

\author{
I Putu Ananda Citra \\ Jurusan Pendidikan Geografi, UNDIKSHA \\ Singaraja, Indonesia
}

e-mail: anandageo07@yahoo.com

\begin{abstract}
Abstrak
Penelitian ini dilaksanakan di wilayah pesisir Kabupaten Buleleng dengan tujuan 1) mendeskripsikan potensi ekowisata yang dimiliki DTW wilayah pesisir Kabupaten Buleleng, 2) Menganalisis peranan masyarakat desa adat untuk pengembangan potensi ekowisata di pesisir Kabupaten Buleleng, 3) memetakan sebaran tingkat potensi ekowisata di kawasan pesisir Kabupaten Buleleng. Metode penelitian yang digunakan dalam penelitian ini adalah survai didukung dengan metode observasi. Pengambilan sampel dengan teknik purposive sampling. Analisis data dilakukan dengan teknik analisis deskriptif kualitatif. Hasil penelitian menunjukkan, 1) Potensi ekowisata yang berada di wilayah pesisir Kabupaten Buleleng secara umum dapat dikembangkan sebagai ekowisata. 2) Peranan Desa Adat dalam pengembangan ekowisata pesisir dalam kategori tinggi. DTW yang dikelola oleh desa adat memberikan tanggung jawab langsung untuk mengembangkan potensi yang dimiliki. 3) Sebaran tingkat potensi ekowisata pada kawasan timur masih perlu ditingkatkan, sedangkan wilayah pesisir bagian dan bagian barat memiliki potensi tinggi. Nilai tertinggi pada pesisir bagian barat. Hal ini karena DTW biorock di Desa Pemuteran melibatkan wisatawan untuk turut menjaga lingkungan dan berpartisipasi dalam melestarikan terumbu karang sebagai daya tarik utama.
\end{abstract}

Kata kunci: Pemetaan, Ekowisata, Wilayah Pesisir

\begin{abstract}
This research was conducted in the coastal areas of Buleleng with the purpose of 1) describe the potential of ecotourism owned DTW coastal areas of Buleleng, 2) to analyze the role of indigenous villagers for potential development of ecotourism in the coastal district of Buleleng, 3) to map the distribution of the level of potential eco-tourism in the coastal area district Buleleng. The method used in this study is a survey supported by the observation method. Sampling with purposive sampling technique. Data was analyzed using qualitative descriptive analysis techniques. Results showed that 1) The potential for ecotourism in the coastal areas of Buleleng in general can be developed as an ecotourism. 2) Role of the Village People in coastal ecotourism development in the high category. DTW managed by indigenous villages provide direct responsibility for developing potential. 3) Distribution rate ecotourism potential in the eastern region still needs to be
\end{abstract}


improved, while the coastal areas and western parts have a high potential. The highest value on the western coast. This is because the DTW biorock in the village of Pemuteran involving tourists to participate in maintaining the environment and participate in the preservation of coral reefs as the main attraction.

Keywords: Mapping, Ecotourism, Coastal Areas

\section{PENDAHULUAN}

Perencanaan pembangunan merupakan jalan untuk mewujudkan aspirasi dan tuntutan masyarakat. Pembangunan yang berpusat pada pertumbuhan telah didorong oleh modelmodel ilmu ekonomi sistem terbuka yang konvensional, yang memandang baik orang (manusia) maupun lingkungan sebagai variabel luar. Selain itu, model pembangunan tersebut percaya melalui efek tetesan ke bawah (trickle down effect), yakni bila terjadi akumulasi kapital dikalangan kelas atas atau pusat, maka kapital itu akan menetes ke bawah. Karena itu lewat mekanisme semacam itu pula perbaikan hidup rakyat pedesaan, yang mayoritas miskin, diharapkan dapat terwujud. Kritik dan kecaman terhadap doktrin developmentalisme itu terus mengalir, mulai dari penganut paradigma kebutuhan pokok, teori ketergantungan sampai dengan pendekatan dan gerakan baru yang mengarah pada pemberdayaan. Gerakan pemberdayaan diawali dari munculnya paradigma pembangunan yang berpusat pada manusia (rakyat), yang diakui sebagai "pembangunan alternatif".

Pariwisata sebagai sub sektor ekonomi, merupakan industri terbesar dan tercepat perkembangannya di dunia. Prioritas pariwisata yang utama dan pertama adalah membangun manusianya, terutama masyarakat lokal dan yang langsung berinteraksi dengan wisatwan agar dapat dicapai kesetaraan dan terjadinya saling pertukaran maupun kerjasama saling menghargai dan memperkaya kehidupan (Baiquni,2010:15). Hal ini berarti, pariwisata selain sebagai sumber pendapatan devisa, media untuk memperluas dan memeratakan kesempatan kerja, mendorong pembangunan daerah, yang paling penting adalah meningkatkan kesejahteraan dan kemakmuran rakyat, media untuk memperkaya kebudayaan nasional agar tetap mempertahankan kepribadian bangsa serta melestarikan fungsi dan mutu lingkungan hidup. Berbekal tekad tersebut, pemerintah mulai memberi perhatian serius untuk sektor pariwisata dan terus menggalakkan kepariwisataan di berbagai daerah sesuai dengan karakter daerah masing-masing. Bali sebagai salah satu daerah tujuan wisata utama di Indonesia banyak memiliki potensi kepariwisataan yang bisa dikembangkan dan ditingkatkan. Kedudukan daerah Bali sudah dapat disejajarkan dengan daerah tujuan wisata lainnya yang ada di dunia.

Walaupun demikian, kesenjangan perkembangan pariwisata di Provinsi Bali masih tetap terjadi yaitu antara Bali bagian utara dengan Bali bagian selatan. Pariwisata seolah putus aktivitasnya di bagian utara Pulau Bali yaitu di Kabupaten Buleleng. Pesatnya perkembangan pariwisata khususnya Jurnal IImu Sosial dan Humaniora |732 
wisata pantai di Bali bagian selatan seperti Pantai Kuta dan Sanur hampir tidak terjadi pada pesisir Buleleng. Padahal Kabupaten Buleleng memiliki pantai terpanjang di Bali yaitu 157,05 $\mathrm{Km}$ (http://Bulelengkab.go.id). Hal ini berarti bahwa potensi yang dimiliki khususnya potensi wisata pesisir sangat besar untuk dikembangkan.

Pengembangan pariwisata harus merupakan pengembangan berencana secara menyeluruh, sehingga dimanfaakan oleh masyarakat, baik segi ekonomi, sosial dan kultural, menghindari timbulnya permasalahan ekonomi, sosial dan kultural yang bersifat negatif. Perencanaan kepariwisataan harus mengintegrasikan pembangunan pariwisata menjadi suatu program pembangunan ekonomi, fisik, sosial, dimana semua itu harus mampu memberikan kerangka kerja kebijaksanan pemerintah untuk memotivasi dan mengendalikan pengembangan kepariwisataan.

Ekowisata dapat menjadi pengantar menuju pariwisata berkesinambungan karena di dalam ekowisata terdapat prinsip pembelajaran tentang alam dimana masyarakat turut mendapatkan manfaatnya (Pendit, 2002:149). Dengan ekowisata diharapkan dapat menjamin keberlangsungan hidup pariwisata tanpa harus mengorbankan lingkungan. Dari prinsip pembelajaran tentang alam dan manfaatnya terhadap masyarakat, maka Bali memiliki potensi besar dalam pengembangan ekowisata karena Bali termasuk Kabupaten Buleleng memiliki sejumlah sumber daya alam dan potensi sosial budaya berupa adat-istiadat masyarakat yang mampu menopang pembangunan pariwisata, bila semua sumber daya alam ini dikelola dengan baik akan dapat menunjang ekowisata, namun jika tidak ia akan menghancurkan bukan saja sektor pariwisata tetapi Bali secara keseluruhan.

Hal ini menarik untuk dikaji karena kawasan ekowisata selain merupakan sumber pendapatan masyarakat juga berfungsi untuk konservasi keanekaraganam hayati dan kelestarian budaya masyarakat lokal. Penelitian tentang pemetaan potensi ekowisata wilayah pesisir di Kabupaten Buleleng dengan tujuan mendeskripsikan potensi ekowisata yang dimiliki DTW wilayah pesisir Kabupaten Buleleng, menganalisis peranan masyarakat desa adat untuk pengembangan potensi ekowisata di pesisir Kabupaten Buleleng, dan memetakan sebaran tingkat potensi ekowisata di kawasan pesisir Kabupaten Buleleng sangat perlu diketahui untuk dapat dimanfaatkan secara optimal sesuai dengan kebutuhan.

\section{METODE}

Penelitian ini dilakukan di
wilayah pesisir Buleleng.Pengambilan sampel obyek wisata dilakukan secara purposive area sampling, karena obyek wisata yang berada di wilayah pesisir Kabupaten Buleleng tersebar dari daerah pesisir bagian timur sampai barat. Pembagian 3 zone wilayah Kabupaten Buleleng dijadikan dasar dalam pengambilan sampel obyek wisata, yaitu sampel obyek wisata yang berada di wilayah pesisir timur (Air Sanih), tengah (Lovina), dan barat (Desa Pemuteran). Pengambilan sampel masyarakat dilakukan secara purposive pada lokasi

Jurnal IImu Sosial dan Humaniora|733 
obyek wisata yang dapat memenuhi syarat atau mewakili untuk kepentingan penelitian, serta mewakili kelengkapan unsur-unsur yang akan diamati dan dinilai berkaitan dengan kegiatan pariwisata di Kabupaten Buleleng.

Data yang dikumpulkan yaitu dengan cara observasi, wawancara, kuisioner dan kajian pustaka. Selanjutnya pengolahan data dengan pengharkatan dan pembobotan pada masing-masing indikator untuk dapat menentukan klas masing-masing. Penyajian data secara deskriptif dengan analisis kualitatif.

HASIL DAN PEMBAHASAN
Potensi ekowisata yang akan dideskripsikan yaitu objek wisata yang berada di wilayah pesisir Kabupaten Buleleng yang telah menjadi sampel penelitian. Objek wisata Air sanih (bagian timur), Objek Wisata Lovina (bagian tengah), dan Objek wisata Pemuteran (bagian barat) pesisir Buleleng. Potensi ekowisata merupakan gabungan dari ketiga aspek ekowisata yang terdiri dari potensi wisata, partisipasi masyarakat, dan kontribusi terhadap masyarakat lokal Western (1995:9). Berikut akan dideskripsikan masing-masing objek untuk memperoleh gambaran yang lebih komprehensip sebagai dasar untuk pengambangan ekowisata.

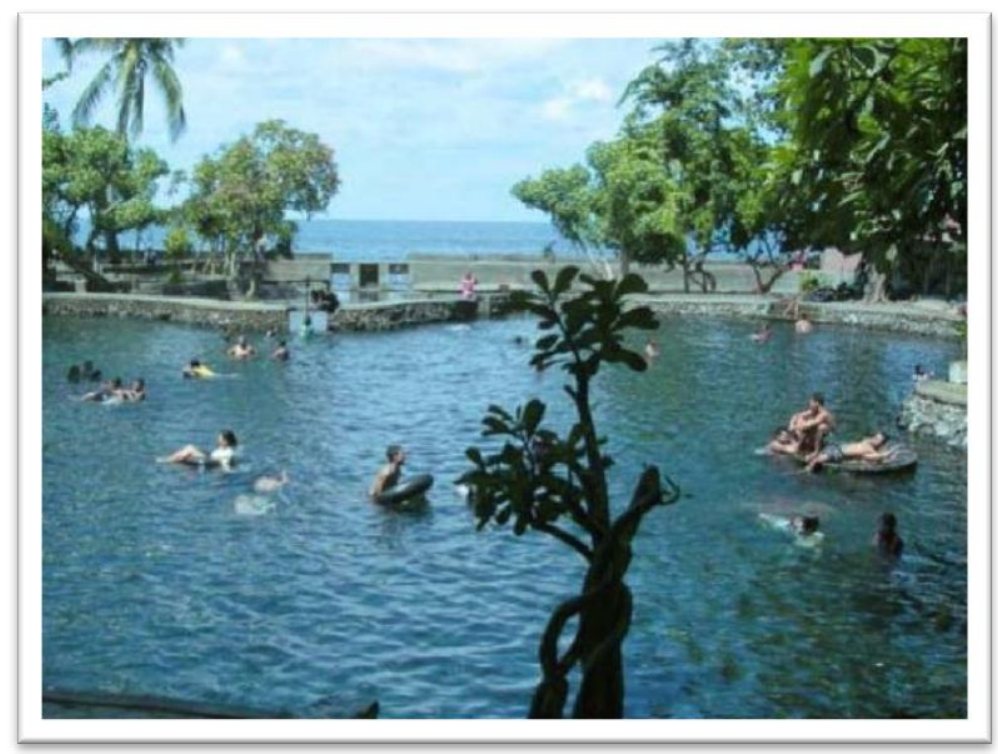

Gambar 1 Air sanih

Potensi wisata merupakan aspek pertama dalam ekowisata yang terkait dengan atraksi wisata yang ada di Air Sanih adalah kolam renang sebagai daya tarik utama dan pemandangan laut sebagai daya tarik pendukung. Aksesibilitas terkait dengan mudah tidaknya suatu lokasi itu dijangkau. Aksesibiltas ke objek wisata tergolong baik ini dibuktikan dengan kondisi jalan 
tergolong baik dan merupakan jalur utama ke kota kabupaten, akan tetapi tergolong sangat jauh dari kota kabupaten dan belum memiliki kendaraan untuk trasportasi. Fasilitas wisata Air Sanih tergolong rendah, ini dibuktikan tidak adanya sarana akomodasi yang dimiliki dan toko souvenir. Fasilitas kesehatan dan informasi juga belum ada, tetapi untuk rumah makan/minum dan pos keamanan sudah ada. Pelestarian lingkungan sudah dilakukan baik petugas kebersihan dan desa adat seniri memiliki aturan dalam menjaga kebersihan lingkungan di sekitar kawasan wisata Air Sanih.

Partisipasi masyarakat merupakan aspek kedua dari ekowisata. Partisipasi terkait keterlibatan masyarakat lokal dalam kegiatan pariwisata. Masyarakat lokal yang dimaksud adalah masyarakat yang berada di sekitar kawasan wisata. Partisipasi masyarakat di Objek wisata Air Sanih secara umum termasuk kategori sedang, dibidang perencanaan, monitoring, dan sebagai pelaku usaha pariwisata masih kurang, hanya saja lebih banyak terlibat dalam bidang pengelolaan seperti menjadi karyawan dan petugas parkir dan kebersihan.

Kontribusi dari kegiatan pariwisata terhadap masyarakat lokal Air Sanih hanya sebatas peningkatan pendapatan dan kesempatan bekerja di objek wisata. Namun kesempatan kerja terkait jasa akomodasi masih belum ada karena hotel dan restoran yang seharusnya menyerap tenaga kerja belum ada.

Dengan demikian potensi ekowisata di Objek Wisata Air Sanih dari ketiga aspek ekowisata yang sudah diuraikan menunjukkan kategori sedang. Hal ini karena partisipasi masyarakat yang masih belum optimal dan belum lengkapnya fasilitas pariwisata. Sedangkan terkait dengan potensi wisata yaitu daya tarik utama dan pendukung sudah merupakat suatu paket atraksi wisata yang menarik.

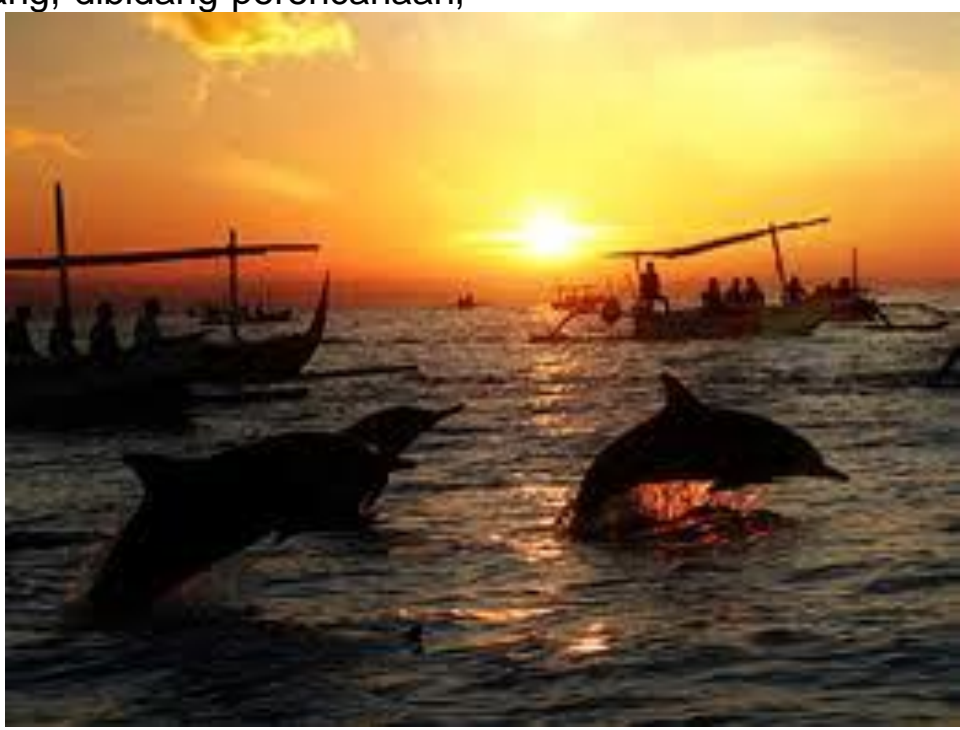

Gambr 2. Pantai Lovina 
Daya tarik utama dari wisata Lovina yakni atraksi lumba-lumba di tengah laut, untuk dapat menikmati atraksi lumba-lumba ini dengan memanfaatkan sampan (perahu kecil) milik nelayan disana, pemandangan ini dapat dinikmati dari pukul 05.00 Wita sampai matahari mulai cukup tinggi. Sedangkan daya tarik pendukung kawasan wisata Lovina yakni pantai dengan panorama yang indah dan intensitas matahari yang cukup menjadikan daya tarik tersendiri bagi wisatawan untuk berdatangan ke daerah wisata Lovina. Lovina terletak sekitar 9 kilometer sebelah barat Kota Singaraja. Kondisi jalan dari ibu kota kabupaten cukup baik, sedangkan untuk transportasi dikawasan wisata Lovina selalu ada, karena berada dekat dengan jalan utama provinsi. Fasilitas yang mendukung wisata Lovina sudah dapat dikatakan lengkap, hanya saja fasilitas pendukung seperti pos kesehatan masih belum tersedia, untuk fasilitas kesehatan hanya dikelola oleh Desa Kalibukbuk itu sendiri seperti puskesmas. Dalam pelestarian lingkungan, seperti desa adat lain di Bali, Desa Adat Kalibukbuk juga menerapkan awig-awig. Seperti melakukan kegiatan pembersihan tiap sebulan sekali disekitar pantai, disamping dilakukan oleh petugas kebersihan yang melakukan setiap harinya. Sedangkan untuk pengolahan limbah, dilakukan hanya sekadar membakar sampah. Karena masingmasing pelaku usaha wisata sudah melaksanakan pengolahan limbahnya sendiri.

Partisipasi masyarakat dalam pengembangan ekowisata di Pantai Lovina sangat penting. Pihak pengelola selalu melibatkan masyarakat lokal yang bekerja di tempat wisata tersebut serta masyarakat lokal yang berada di sekitar pantai. Mereka selalu diberikan surat untuk menghadiri rapat maupun seminar yang diadakan oleh pihak pengelola dan dinas pariwisata. Contohnya, yaitu Dinas Kebudayaan dan Pariwisata mengadakan

Seminar Sehari Anak Agung Panji Tisna pada tanggal 24 September 2013. Masyarakat lokal ikut berpartisipasi dalam perencanaan, yaitu ikut dalam rapat, identifikasi masalah, dan pengambilan keputusan. Selain itu, masyarakat lokal juga dilibatkan apabila ada monitoring atau pengawas yang datang meninjau keadaan Pantai Lovina. Pengelolaan tempat wisata juga melibatkan masyarakat lokal yang ikut mejadi bagian dari Pantai Lovina. Partisipasi pengelolaan yang melibatkan masyarakat lokal yaitu petugas parkir, petugas keamanan, pemandu wisata, petugas kebersihan, serta karyawan. Pengusaha atau pelaku ekonomi ekowisata yang ada seperti pedagang souvenir, rumah makan atau restoran, jasa transportasi, serta akomodasi juga selalu dilibatkan dalam pengelolaan wisata Pantai Lovina.

Kontribusi dari kegiatan

pariwisata Pantai Lovina terhadap masyarakat lokal sangat besar. Kegiatan pariwisata di Pantai Lovina mempengaruhi sosial ekonomi masyarakat lokal, seperti bertambahnya pendapatan masyarakat yang bekerja di Lovina. Tenaga kerja tersebut dapat diambil dari masyarakat lokal yang berada di sekitar Pantai Lovina. Disediakannya tempat untuk berjualan souvenir oleh pihak pengelola yang jumlahnya lebih dari satu membuka

Jurnal IImu Sosial dan Humaniora |736 
peluang bagi masyarakat lokal untuk berjualan di tempat tersebut. Hal ini dapat menambah penghasilan masyarakat. Oleh karena itu, tempat wisata Pantai Lovina memberikan kontribusi tinggi terutama dalam bidang ekonomi kepada masyarakat lokal.

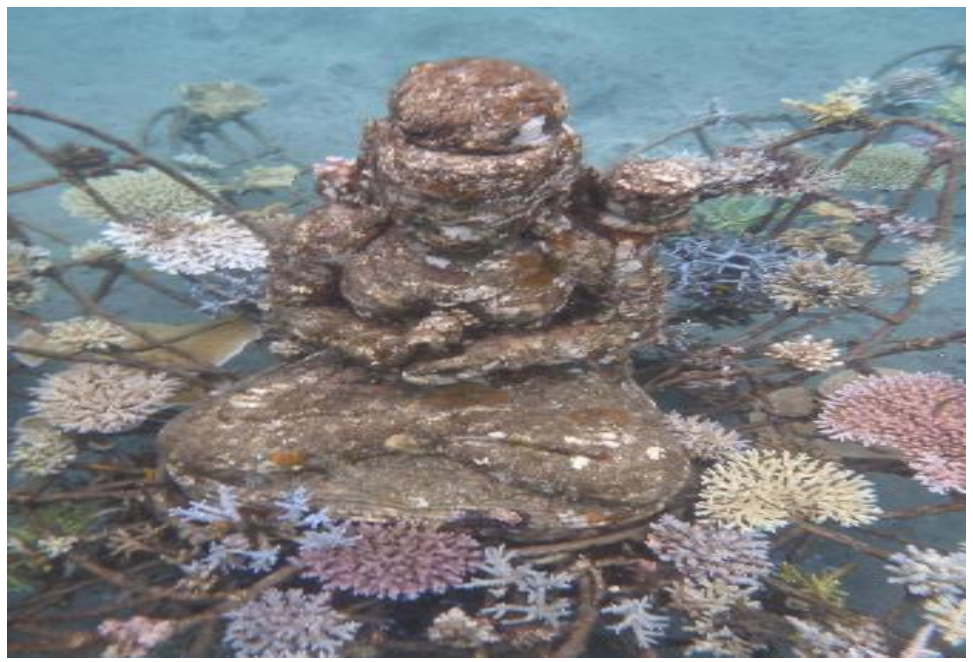

Gambar 3 Biorock Pemuteran

Potensi wisata Desa Pemuteran memiliki daya tarik utama berupa keindahan alam bawah laut dengan adanya rehabilitasi terumbu karang melalui sistem Biorock. Metode Biorock dipilih karena dapat mempercepat pertumbuhan terumbu karang yang akan mengundang ikan dan biota laut lainnya untuk hidup dan berkembang dalam sebuah ekosistem yang sehat. Terdapat daya tarik pendukung lainnya Pemuteran sebagai objek wisata alam, yakni tempat meditasi yang ada di Pura Pemuteran, tempat tracking dan air terjun (yang rencananya akan dijadikan objek pengembangan wisata Desa Pemuteran untuk tahun 2014).

Masyarakat lokal yang dilibat dalam pengembangan ekowisata ini adalah dengan diikutsertakan dalam perencanaan terkait rapat-rapat, pengambilan peputusan dan identifikasi permasalahan yang ada di wilayah wisata. Selain itu masyarakat lokal juga dilibatkan dalam monitoring dengan pembentukan "Pecalang"(petugas keamanan adat) untuk memantau terumbu karang yang dikembangkan agar terhindar dari orang-orang yang tak bertanggung jawab. Pelaku wisata juga turut serta dalam pengelolaan wisata salah satunya dengan membentuk Organisasi Transportasi Pemuteran yang dikembangkan untu melihat secara umum kondisi di Desa Pemuteran. Terakhir, dalam penyerapan tenaga kerja, yaitu ada peraturan 80 : 20 yang memiliki makna penduduk atau masyarakat lokal memiliki persentase $80 \%$ yang harus diutamakan dalam penyerapan tenaga kerja dan sisanya sejumlah $20 \%$ berasal dari luar

Jurnal IImu Sosial dan Humaniora |737 
masyarakat lokal yang langsung disampaikan oleh Komang Astika Kontribusi dari kegiatan pariwisata di Desa Pemuteran terhadap masyarakat lokal mempengaruhi sosial ekonomi masyarakat lokal, seperti bertambahnya pendapatan masyarakat dan terciptanya kesempatan/peluang kerja. Tenaga kerja tersebut diambil dari masyarakat Desa Pemuteran. Disediakannya tempat untuk berjualan souvenir oleh pihak pengelola yang jumlahnya lebih dari satu membuka peluang bagi masyarakat lokal untuk berjualan di tempat tersebut. Hal ini dapat menambah penghasilan masyarakat. Oleh karena itu, tempat wisata Desa Pemuteran memberikan berkontribusi tinggi terutama dalam bidang ekonomi kepada masyarakat lokal.

\section{Peranan Desa Adat dalam pengembangan Ekowisata Wilayah Pesisir}

Terdapat tiga hal yang menjadi bidang peranan dari desa adat, yaitu peranan dibidang atraksi wisata, di bidang fisik dan sosial ekonomi. peranan terhadap atraksi wisata baik daya tarik utama dan pendukung terus dilkakukan perawatan dan perbaikan. Pada bidang fisik, dilakukan program perbaikan berdasarkan kajian dan kondisi di objek dan perkembangan kunjungan wisatawan. Program perbaikan DTW pemandian Air Sanih akan dilakukan penataan dan penambahan kolam renang serta melengkapi fasilitas penunjang yang selama ini masih minim. Desa adat belum dapat melengkapi fasilitas akomodasi wisata karena investor yang masih jarang. Akan tetapi mengenai peran di bidang sosial dan ekonomi, desa adat telah menetapkan aturan dalam kegiatan pariwisata seperti penerimaan tenaga kerja yang diutamakan masyarakat lokal dan terdapat aturan untuk menghindari terjadinya pelanggaran.

Dalam kegiatan pariwisata di Lovina terdapat hubungan timbal balik antara kegiatan wisata dengan Desa adat. Dalam pengembangan wisata pesisir di kawasan Lovina masyarakat dilibatkan secara aktif dalam pengembangannya sebagai pelaku usaha wisata (pedagang cendera mata, makanan dan minuman) maupun dalam menjaga kebersihan. Peranan desa adat dalam pengembangan wisata di Pantai Lovina meliputi, peranan terhadap atraksi wisata seperti berpastisipasi aktif dalam even lovina festifal, sarana fisik seperti infrastruktur.

Masyarakat dalam pengembangan potensi daya tarik wisata di Desa Pemuteran sangat partisipatif. Hal itu terlihat dari perencaan, monitoring, pengelolaan, hingga pelaku ekonominya melibatkan masyarakat, selain itu kebersihan pada objek daya tarik wisata tersebut juga ikut melibatkan masyarakat dalam bentuk kerja bakti untuk bersih-bersih. Dalam hal perencanaan, masyarakat dilibatkan dalam rapat-rapat, pengambilan keputusan, pengidentifikasian masalah, dan promosi wisatanya. Seperti contoh pada hal promosi wisata, masyarakat diikutkan dalam penyebaran brosurbrosur. Dalam hal monitoring, masyarakat diikut sertakan dalam mengawasi proses-proses berlangsungnya kegiatan kepariwisataan di desa tersebut. Dalam hal pengelolaan, masyarakat 
diikutsertakan sebagai petugas keamanan yang tergabung dalam pecalang laut. Selain itu dalam hal pengelolaan masyarakat juga dilibatkan sebagai pemandu wisata, petugas kebersihan dan karyawan. Dalam pelaku usaha ekonominya, masyarakat ikut membuka usaha cendera mata, rumah makan.

Masyarakat di Desa Pemuteran dalam upaya pengelolaan daya tarik wistata memiliki andil besar, secara umum masyarakat Desa Pemuteran menggantungkan pendapatan rumah tangganya melalui sektor pariwisata, seiring dengan adanya beberapa sekolah kejuruan pada bidang pariwisata di Kabupaten Buleleng, menjadi pendorong dalam peningkatan kualitas sumber daya manusianya. Terdapat daerah konservasi koral di Desa Pemuteran khususnya di Kawasan Pura Segara, yang secara optimal mengupayakan pengembangan koral, kemudian untuk menarik minat wisatawan dibuka pula jasa penyedia layanan diving.

\section{Sebaran Tingkat Potensi Ekowisata Di Wilayah Pesisir Kabupaten Buleleng}

Masing-masing objek diukur potensi wisatanya untuk mengetahui tingkat potensi untuk dikembangkan sebagai ekowisata. Tiap aspek ekowisata yang diukur dengan memberikan harkat pada masingmasing indikator. Pemberian harkat dengan skala 1 - 3 dengan rincian sebagai berikut.

- Harkat 1 menunjukkan "potensi rendah"

- Harkat 2 menunjukkan "potensi sedang"
- Harkat 3 menunjukkan "potensi tinggi"

Masing-masing aspek ekowisata memiliki beberapa indikator, sehingga perlu adanya klasifikasi masing-masing. Aspek Potensi Wisata terdiri dari 16 indikator, nilai terendah adalah 16 dan tertinggi 48, maka dapat dihitung kelas intervalnya dengan rumus sebagai berikut.

$$
\text { Interval }=
$$

Jumlah nilai tertinggi-jumlah nilai terendah

Jumlah kelas
Interval $=\frac{48-16}{3}$
Interval $=10,67$
Dengan demikian dapat dibuat
klasifikasi aspek ekowisata sebagai
berikut.

$16-26,67=$ rendah

$26,68-37,35=$ sedang

$37,36-48=$ tinggi

Aspek partisipasi masyarakat terdiri dari 14 indikator, nilai terendah adalah 14 dan tertinggi 42, maka dapat dihitung kelas intervalnya dengan rumus sebagai berikut.

Interval

$=\frac{\text { Jumlah nilai tertinggi }- \text { jumlah nilai terendah }}{\text { Jumlah kelas }}$

Interval $=\frac{42-14}{3}$

Interval $=9,33$

Dengan demikian dapat dibuat klasifikasi aspek ekowisata sebagai berikut.

$14-23,33=$ partisipasi rendah 23,34 $-32,67=$ partisipasi sedang $32,68-42=$ partisipasi tinggi

Aspek kontribusi terdiri dari 7 indikator, nilai terendah adalah 7 dan tertinggi 21, maka dapat dihitung kelas

Jurnal IImu Sosial dan Humaniora|739 
intervalnya dengan rumus sebagai Dengan demikian dapat dibuat berikut. klasifikasi peranan desa adat sebagai berikut.

Interval

$10-16,67=$ peranan rendah

Jumlah nilai tertinggi - jumlah nilai terendah

$16,68-23,35$

= peranan sedang

Interval $=\frac{21-7}{3}$ Jumlah kelas

$23,36-30$

$=$ peranan tinggi

Interval $=4,66$

Dari hasil klasifikasi masingmasing aspek ekowisata yang telah diuraikan, maka dengan

Dengan demikian dapat dibuat klasifikasi aspek kontribusi terhadap masyarakat sebagai berikut.

$7-11,66=$ kontribusi rendah

$11,67-16.33=$ kontribusi sedang

$16,34-21=$ kontribusi tinggi

Aspek Peranan Desa Adat terdiri dari 10 indikator, nilai terendah adalah 10 dan tertinggi 30, maka dapat dihitung kelas intervalnya dengan rumus sebagai berikut.

Interval $=\frac{\text { Jumlah nilai tertinggi }- \text { jumlah nilai terendah }}{\text { Jumlah kelas }}$

Interval $=\frac{30-10}{3}$

Interval $=6,67$ menggabungkan semua aspek maka diperoleh potensi ekowisata memiliki 35 indikator sehingga nilai terendah adalah 35 dan nilai tertinggi adalah 105, maka dapat dihitung kelas interval dengan rumus berikut.

Interval $=\frac{\text { Jumlah nilai tertinggi }- \text { jumlah nilai terendah }}{\text { Jumlah kelas }}$

Interval $=\frac{111-37}{3}$

Interval $=24,67$

Dengan demikian dapat dibuat tingkat klasifikasi tingkat potensi ekowisata sebagai berikut.

$37-61,67=$ tingkat potensi rendah

$61,68-86,35=$ tingkat potensi sedang

$86,36-111=$ tingkat potensi tinggi

Tabel 1. Tingkat Potensi Ekowisata Wilayah Pesisir Kabupaten Buleleng

\begin{tabular}{|l|l|c|c|c|c|}
\hline \multirow{2}{*}{ No } & \multirow{2}{*}{$\begin{array}{c}\text { Objek } \\
\text { Wisata }\end{array}$} & $\begin{array}{c}\text { Potensi } \\
\text { Wisata }\end{array}$ & $\begin{array}{c}\text { Aspek Ekowisipasi } \\
\text { Masyarakat }\end{array}$ & $\begin{array}{c}\text { Kontribusi terhadap } \\
\text { Masyarakat Lokal }\end{array}$ & $\begin{array}{c}\text { Potensi } \\
\text { Ekowisata }\end{array}$ \\
\cline { 3 - 5 } & Air Sanih & $\begin{array}{c}37 \\
\text { (sedang) }\end{array}$ & $\begin{array}{c}28 \\
\text { (sedang) }\end{array}$ & $\begin{array}{c}16 \\
\text { (sedang) }\end{array}$ & $\begin{array}{c}81 \\
\text { (Sedang) }\end{array}$ \\
\hline 2 & Lovina & $\begin{array}{c}41 \\
\text { (tinggi) }\end{array}$ & $\begin{array}{c}38 \\
\text { (tinggi) }\end{array}$ & $\begin{array}{c}19 \\
\text { (tinggi) }\end{array}$ & $\begin{array}{c}98 \\
\text { (Tinggi) }\end{array}$ \\
\hline 3 & Pemuteran & $\begin{array}{c}43 \\
\text { (tinggi) }\end{array}$ & $\begin{array}{c}38 \\
\text { (tinggi) }\end{array}$ & $\begin{array}{c}21 \\
\text { (tinggi) }\end{array}$ & (Tinggi) \\
\hline
\end{tabular}




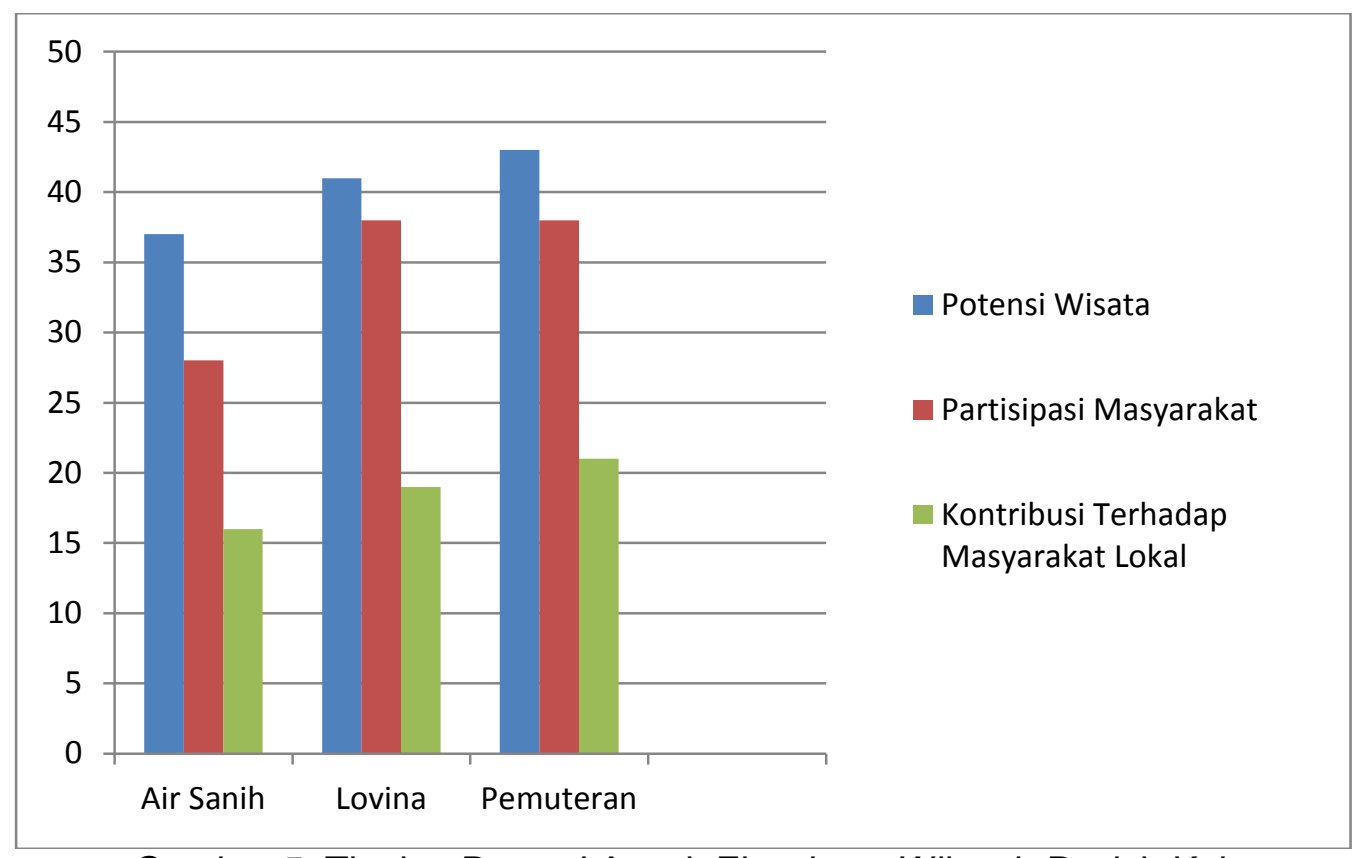

Gambar 5. Tingkat Potensi Aspek Ekowisata Wilayah Pesisir Kabupaten Buleleng

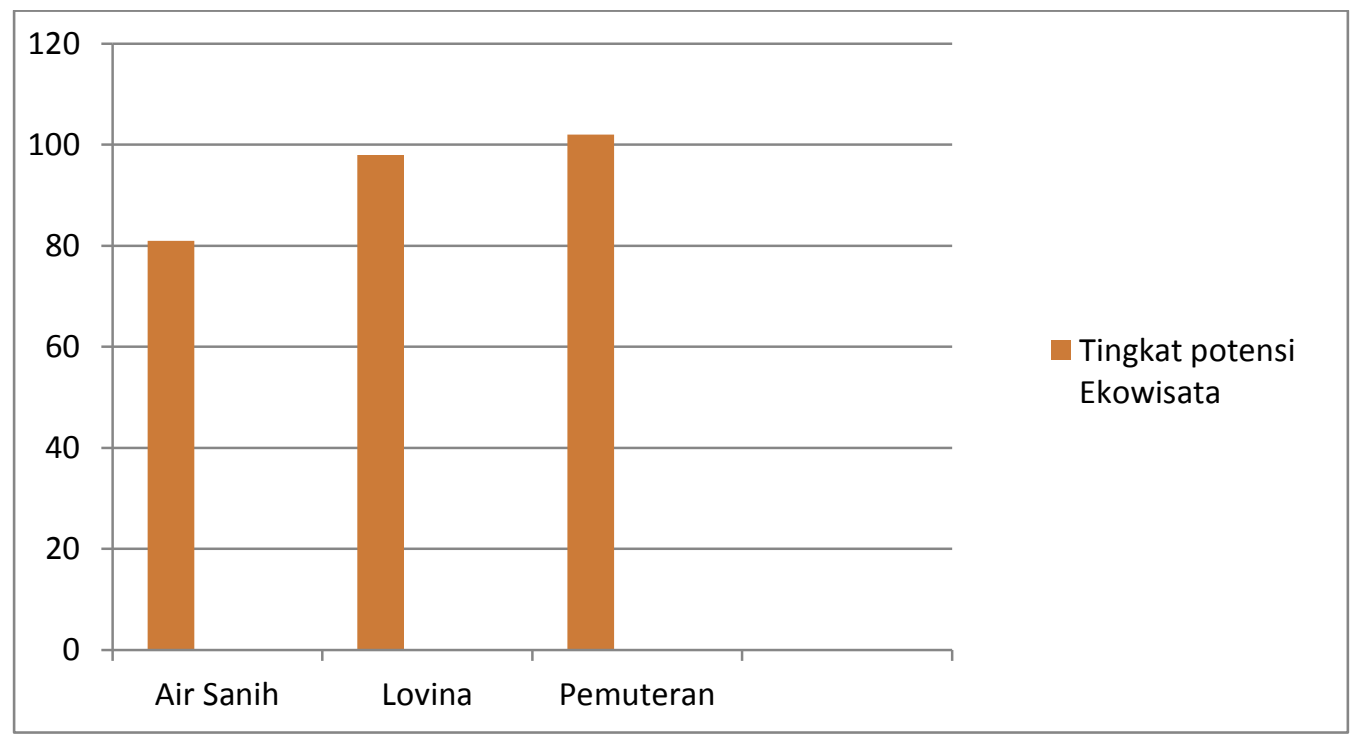

Gambar 6. Tingkat Potensi Ekowisata Wilayah Pesisir Kabupaten Buleleng

Berdasarkan Tabel 1 dan Gambar 4, 5 dan 6 tersebut, tingkat potensi ekowisata dibedakan menjadi 2 (dua) yakni, 1) objek wisata Air Sanih tingkat potensi ekowisata tergolong sedang. Hal ini karena aspek pada masing-masing Jurnal IImu Sosial dan Humaniora |741 
ekowisata menunjukkan potensi sedang, seperti pada aspek potensi wisata dengan kategori potensi sedang, aspek partisipasi masyarakat dengan kategori sedang, dan aspek kontribusi pariwisata terhadap masyarakat lokal juga kategori sedang. Dari semua aspek tersebut akan berpengaruh pada potensi ekowisata di objek wisata air sanih termasuk kategori sedang untuk pengembangan ekowisata. Banyak hal yang perlu diperbaiki agar sesuai dengan syarat dari pengembangan ekowisata, mulai dari pengembangan potensi wisata, meningkatkan parisipasi masyarakat dan membuka peluang usaha sehingga dapat meningkatkan pendapatan masyarakat di sekitar kawasan wisata. 2) tingkat potensi tinggi untuk pengembangan ekowisata berada pada objek wisata Lovina dan Pemuteran. Hal ini dapat dilihat dari ketiga aspek ekowisata mulai dari potensi wisata, partisipasi masyarakat, dan kontribusi terhadap masyarakat lokal dari hasil pengolahan data berada pada potensi tinggi.

Dari uraian diatas maka dapat dipetakan sebaran tingkat potensi ekowisata pada kawasan pesisir Kabupaten Buleleng, dimana kawasan timur Kabupaten Buleleng potensi ekowisatanya masih perlu ditingkatkan, sedangkan wilayah pesisir bagian tengah (Lovina) dan bagian barat (Pemuteran) Kabupaten Buleleng memiliki potensi tinggi untuk pengembangan ekowisata. Walaupun pesisir tengah dan pesisir barat samasama memiliki potensi ekowisata yang tinggi, nilai tertinggi diperoleh oleh pesisir bagian barat. Hal ini karena objek wisata biorock di Desa Pemuteran melibatkan wisatawan untuk turut menjaga lingkungan dan berpartisipasi dalam melestarikan terumbu karang sebagai daya tarik utama. Syarat pengembangan ekowisata sudah tegas menyatakan ketiga aspek ekowisata menjadi syarat mutlak sebagai dasar dalam mengembangkan suatu objek wisata. Kegiatan pariwisata harus memperhatikan kelestarian lingkungan, melibatkan masyarakat khususnya masyarakat lokal, dan kegiatan pariwisata harus memberikan keuntungan. Hal ini juga sejalan dengan makna dari pembangunan berkelanjutan yang menjadi prioritas pembangunan di Indonesia.

\section{PENUTUP}

Berdasarkan hasil dan pembahasan dari tujuan penelitian, dapat ditarik kesimpulan sebagai berikut.

1) Potensi ekowisata yang berada di wilayah pesisir Kabupaten Buleleng secara umum dapat dikembangkan sebagai ekowisata. Walaupun terdapat objek wisata yang perlu untuk meningkatkan ketiga aspek ekowisata yang terdiri dari potensi wisata, partisipasi masyarakat, dan kontribusi terhadap masyarakat lokal sehingga sesuai dengan syarat dari ekowisata.

2) Peranan Desa Adat dalam pengembangan ekowisata pesisir di Kabupaten Buleleng sudah baik dalam kategori memiliki peranan yang tinggi. DTW yang dikelola oleh desa adat memberikan tanggung jawab langsung untuk mengembangkan potensi yang dimiliki untuk meningkatkan kunjungan wisatawan 
3) Sebaran tingkat potensi ekowisata pada kawasan pesisir Kabupaten Buleleng, dimana kawasan timur Kabupaten Buleleng (Air Sanih) potensi ekowisatanya masih perlu ditingkatkan, sedangkan wilayah pesisir bagian tengah (Lovina) dan bagian barat (Pemuteran) Kabupaten Buleleng memiliki potensi tinggi untuk pengembangan ekowisata. Walaupun pesisir tengah dan pesisir barat sama-sama memiliki potensi ekowisata yang tinggi, nilai tertinggi diperoleh oleh pesisir bagian barat. Hal ini karena objek wisata biorock di Desa Pemuteran melibatkan wisatawan untuk turut menjaga lingkungan dan berpartisipasi dalam melestarikan terumbu karang sebagai daya tarik utama.

1) Bagi Pemerintah Kabupaten Buleleng dalam rangka pengelolaan pengembangan wilayah khususnya pengelolaan wilayah pesisir dalam bidang pariwisata agar mulai untuk berorietasi pada pengembangan ekowisata. Objek wisata pesisir di kabupaten Buleleng dari hasil penelitian ini memiliki potensi dan terdapat objek wisata yang memenuhi persyaratan pengembangan ekowisata.

2) Bagi Desa Adat agar menjadikan awig-awig desa sebagai bingkai kegiatan pariwisata. DTW yang ada di bagian wewidangan (areal desa) wajib mentaati kearifan lokal yang dimiliki desa adat, sehingga kelestarian budaya yang dimiliki tidak pudar.
3) Bagi pengelola objek wisata agar lebih memperhatikan kelestarian atraksi wisata sebagai daya tariknya, melibatkan masyarakat lokal lebih banyak dengan membuka peluang usaha sehingga masyarakat akan sebagai subjek dalam kegiatan pariwisata.

\section{UCAPAN TERIMAKASIH}

Terimakasih pada Universitas Pendidikan Ganesha dan Lembaga Penelitian Undiksha khususnya dalam memberikan kesempatan, izin dan kontribusi berupa dana penelitian dengan nomor surat kontrak penelitian: 38/UN48.14/PL/2015 sehingga penelitian dapat berjalan dan selesai tepat waktu.

\section{DAFTAR PUSTAKA}

Baiquni, M. 2010. Pariwisata Berkelanjutan dalam Pusaran Krisis Global. Denpasar: Udayana University Press.

Efendi, Sofian dan Singarimbun, Masri. 1987. Metode Penelitian Survai. Yogyakarta: LP3ES

Pendit. 2002. IImu Pariwisata Sebuah Pengantar Perdana. Jakarta : Pradnya Paramitha.

Western, David. 1995. Ekoturisme: Petunjuk Untuk Perencanaan \& Pengelolaan. Jakarta: The Ecotourism Society North Benington, Vermont.

http://www.bulelengkab.go.id/index.php/ pariwisata/19/Wisata-Alam Diakses tanggal 15 April 2013. 